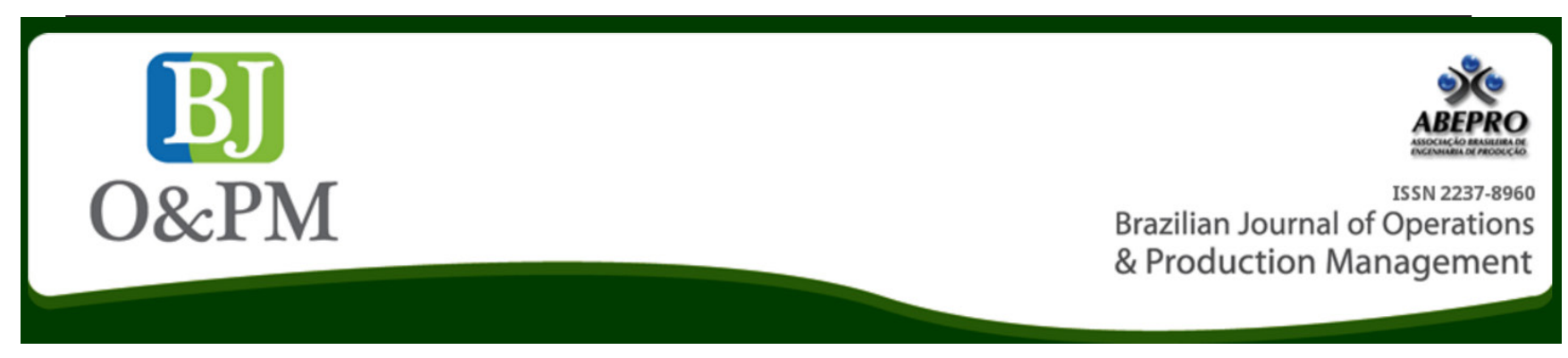

\title{
THE KNOWLEDGE MANAGEMENT IN BUSINESS STRATEGIES AND REVERSE LOGISTICS
}

Jorge Muniz Jra; Julio Cicero Cunha ${ }^{a}$; Reinaldo Almeidaa; Fernando Augusto Silva Marins ${ }^{a}$

a São Paulo State University (UNESP) - São Paulo, SP, Brazil

\begin{abstract}
Environmental issues have changed the behavior of society and, consequently, the business environment. This has narrow approach with Knowledge Management techniques (KM) to promote their processes. However, despite the increase in research in this field, there is still lack of further study in the KM interface and the business environment, as suggested by several researchers. This work, in particular, seeks to identify the main gaps in the literature involving KM and Reverse Logistics (LR), and proposes relevant studies and hitherto insufficiently treated in the literature. For this 8.682 references were analyzed and these only 37 deal with such interface. So this paper proposes 6 topics to be researched.
\end{abstract}

Keywords: Knowledge Management; Reverse Logistics. 
Brazilian Journal of Operations \& Production Management Volume 14, Número 1, 2017, pp 28-36 DOI: 10.14488/BJOPM.2016.v14.n1.a4

\section{INTRODUTION}

The Executive Board of Reverse Logistics (Reverse Logistics Executive Council - RLEC, 2014) defines Reverse Logistics (RL) as the planning, implementation and control of the flow of raw materials, goods in process and finished products, from the points consumption by the points of origin, aiming to recapture value or identify the appropriate disposition.

Manage the product return is a matter of great importance for manufacturers and retailers that can have financial return on these assets. However, many companies still do not recognize the potential value in financial terms, to the environment and image with its customers, which can represent the product recovery activities, waste materials, and its packaging (ATASU et al., 2008). However, gradually this scenario has changed as the concepts of the Triple Bottom Line (TBL) are consolidated in the world.

TBL extends its focus beyond traditional economic objectives, balancing these with ecological and social perspectives (HOLLOS et al., 2012). The same authors point out that from a practical point of view, the incorporation of this vision consists in the strategic objectives of the companies reduces the costs of organizing and increase operational performance.

Ekwueme et al. (2013) points out that concerns about the TBL have pressured organizations to become socially sustainable. Thus, since there is a perception that organizations have a better growth outlook when devote more attention to corporate responsibility initiatives, environmental ethics and social. In a context of great competition, Nonaka (1991) notes: "In an economy where the only certainty is uncertainty, the one sure source of lasting competitive advantage is knowledge."

Kamya et al. (2010) state that the ability of an organization to leverage the knowledge and continuing education from the environment is an important source to achieve a sustainable competitive advantage.

"Knowledge management is the set of systematic, formal and deliberate actions to capture, preserve, share and reuse tacit and explicit knowledge created and used by people during routine and improvement productive processes, generating measurable results for the organisation and for the individuals" (MUNIZ et al., 2009). This definition is used in this work due to its adequacy to the Operations Management.

The KM, created initially as a capture process, distribution and effective use of knowledge, adds more value to the extent that perpetuates the core competencies of companies.

Nonaka et Toyama (2003) argue that the knowledge and the ability to create and use it is considered the most important source of sustainable competitive advantage of organizations. Then the KM strengthens the organizations providing its competitiveness develops and organizes these essential intangible assets for maintaining the economic level and production.

Mihi-Ramirez et al. (2011) point out that LR processes show a high degree of uncertainty and that the GC can be used for your better understanding, development and conduct. These authors claim that the KM and the RL play a key strategic role for the company both of which have a close relationship of support and that its use would provide major benefits to the company, giving greater flexibility to respond to continuous changes of these activities.

According to Mihi-Ramirez et Girdauskiene (2013) the integration of organizational GC and LR systems, provide greater flexibility and ability to anticipate the evolutionary changes that occur in a highly uncertainty competitive environment. These authors found that companies that implemented the RL and KM systems achieved a significant improvement in performance.

Tseng (2008) claims that the association between corporate performance and aspects of the GC has not been adequately explored in the literature. Have Wong \& Aspinwall (2006) show that the GC has become a strategically important tool to improve the business performance and competitiveness.

Thus, the objective of this paper is to explore the themes of Corporate Strategy, RL and KM publications in order to identify the main gaps cited by researchers who have been studying these subjects and their interfaces.

The research method adopted involves a systematic review of the literature using the databases Web of Science, seeking to identify the most relevant articles in terms of number of citations. The identification of the most referenced in the literature researchers used the tool Citespace.

CiteSpace developed by Chaomei Chen, Drexel University, is a Java application that allows analysis and visualization of co-citation networks. It was designed with the aim of helping researchers better understand the evolution, development and trends in a particular scientific area (WENYU; HAIBO, 2013).

This work discusses issues to be addressed in future work and provides a reflection managers for decision making on increasing efficiency in RL processes, therefore an important contribution to the industry and logistics organizations.

This paper is organized as follows. Section 2 presents the result of a Systematic Literature Review in RL subjects, KM, Supply Chain and Business Performance. In Section 3 the method is detailed. In the Section 4 presents the results and suggestions for the continuity of this work and, finally, in Section 5 are the conclusions and observations of the authors, followed by references consulted. 


\section{SYSTEMATIC LITERATURE REVIEW}

This chapter examines the main issues involved in decision-making process linked to RL issues, $\mathrm{KM}$ and the business results expected by the strategic use of such knowledge.

\subsection{Reverse logistics}

The term sustainability is generally defined as the use of resources to meet the needs of the present without compromising the ability of future generations to meet their own needs (DALY; COBB, 1994). Sustainability and sustainable development are subjects that showed a dramatic increase of discussion in recent decades in various fields of academic research: from materials science to environmental sciences (LINTON et al., 2007).

New initiatives are being proposed or adopted by both the public sector and the private sector, in response to growing concern about sustainability (LINTON, 2007). One such approach is the RL. Such logistics involves planning, implementation and control efficiently the flow of raw materials, stock in process, finished products and relevant information on consumption, the recovery of the value of the product or proper disposal (ROGERS; TIBBEN-LEMBKE, 1998). RLServices include return products, recycling, material substitution, elimination of waste, remanufacturing, repair and remodeling (STOCK et al., 2002).

Many studies have also suggested that the RL activities are more complex to manage than traditional logistics (AMINI et al., 2005). Such complexity derives from the uncertainty of the time of return, the return amount of material and quantity of waste products to be returned or delivered to consumers (FLEISCHMANN et al., 1997).

While it may present greater difficulty to manage RL, reuse of materials in manufacturing and savings from the use of returnable packaging have brought significant gains, which encourages the efforts in the development and improvement of reverse processes. Dowlatshahi (2000) estimates that these returns represent $40 \%$ to $60 \%$ of the production cost of a new item.

Environmental standards and raw materials into smaller amounts intensified the importance of $L R$ at an increasing rate (ILGIN; GUPTA, 2010). However, as stated Amini et al., (2005), a company, to implement an effective RL in daily operations, can develop a competitive advantage and increase revenue in a highly competitive market (AMINI et al., 2005). Hernandez (2011) et Milk (2012), in their research confirms that companies implement the reverse logistics operations primarily in the pursuit of economic benefits.

In addition to the economic benefits created by the implementation of LR activities, Wadhwa et Madaan (2004;
2007) et Mihi-Ramirez et Giurdaskiene (2013) conducted research to examine the relationship between reverse logistics and the creation and management of knowledge for development of competitive advantages.

\subsection{Knowledge Management}

Studies such as Nonaka et Takeuchi (1995) et Li et al. (2009) have shown the crucial role of knowledge to achieve organizational success, moreover, Wadhwa et Madaan (2007) state that the RL, the process of knowledge creation also plays an important role.

Whatever the perspective when analyzing knowledge creation in RL, a key element in this process is information (STENTOFT; HALLDORSSON, 2002). However, the high uncertainty in RL processes make the task of planning and control of these very complex information. Information in RL activities has many origins (WADHWA; MADAAN, 2007). Moreover, the flow of information has a gap compared to the physical flow of goods, this is the information generated by a physical process can arrive after the arrival of the goods (MIHI-RAMIREZ et al., 2011).

The KM is important to help manage all this information, lags information and knowledge generated in various functional points in RL and to determine which is the best way to handle them (MIHI-RAMIREZ et al., 2011). The proper storage of such information is particularly critical to achieve efficiency in operations RL (DAUGHERTY et al., 2002).

The creation, maintenance and management of all knowledge generated by $\mathrm{RL}$ activities are essential to minimize the degree of uncertainty (WADHWA; MADAAN, 2007). To reduce it, consequently, all the decision-making process, coordination of activities and RL planning is facilitated. In addition, the company becomes more flexible to expand its capacity to respond to the continuous changes in such activities (MIHI-RAMIREZ; GIRDAUSKIENE, 2013), resulting in competitive advantage.

Mihi-Ramirez et Girdauskiene (2013) conducted an empirical research, which confirmed that the creation of knowledge positively affects the RL.

In the meantime, it positively affects the distribution of information flexibility and positively influences the organization's results. Therefore, it can be deduced that knowledge creation also indirectly affects the flexibility of distribution of information and results. Then, with these results, it can be said that there is a case knowledge of RL activities and flexibility of information elements which constitute the strategic business direction. 
Brazilian Journal of Operations \& Production Management Volume 14, Número 1, 2017, pp 28-36 DOI: 10.14488/BJOPM.2016.v14.n1.a4

\subsection{Sharing information as a strategy in the Supply Chain}

As highlighted by Stentoft et Halldorsson (2002) a key element in the process of knowledge creation is information (STENTOFT; HALLDORSSON, 2002). Information is generated in the various links in the supply chain. Information technology may have the task of assisting in the integration and improve the efficiency of information transfer between the entire supply chain (RADSTAAK; KETELAAR, 1998). This technology can enhance the KM and facilitate the planning of RL activities.

However, this information is not always shared among the partners of the supply chain. Divergent interests and opportunistic behavior of logistics links and information asymmetries throughout the supply chain affect the quality of information (FELDMANN; MÜLLER, 2003). Add to this the difficulty within organizations to share more information than strictly necessary to achieve commercial operation (BERRY et al., 1994).

Lalonde (1998) considers the sharing of information as one of the five building blocks featuring a supply chain with strong relationship. Share the data available with the other parts of the supply chain can become a source of competitive advantage for the entire chain (NOVACK et al., 1995). Chen et Paulraj (2004) emphasize that firms compete not in units but as supply chains, with the need for an integrated approach to planning and control of materials, services and information flows that add value for customers.

Therefore, the information sharing is important for competition throughout the supply chain and the significance of its impact on the management of supply chain depends on what information is shared, when, how and with whom it is shared (HOLMBERG, 2000). And because it is a matter of competitiveness, that decision becomes strategic for all logistics activities, including the RL. As pointed out by Cheng et Lee (2010), most studies in RL focuses on tactical and operational issues and very rarely address strategic level decisions.

\subsection{Performance indicators}

Metrics and Key Performance Indicators (KPIs) provide a refinement of information, shared or not, that are created throughout the supply chain (MELNYK et al., 2004). These authors state that KPIs are means of data processing volume and simultaneously increase the wealth of information, enabling all activities in the supply chain to operate more effectively.

The metrics used in LR are not necessarily the same as those applied in traditional logistics. However, as pointed out by Hall et al. (2013), LR is emerging as a proper field and generally KPIs applied in this area come from the traditional logistics and such practice is not the best
Although there is no direct development of KPIs for RL in 1997, Elkington (1997) proposed a new organizational performance measurement tool: the Triple Bottom Line (TBL). This new idea is to present the economic, environmental and social performance of the organization in a balanced way (SKOULOUDIS et al., 2009). That is, the company's responsibilities are broader than just economic aspects (HUBBARD, 2006).

Environmental aspects are related to the resources used in its operation, such as energy and water, and the resulting products of this production, as gases and chemical waste (HUBBARD, 2006). With many governments in the world decreeing that companies should include non-financial aspects such as environmental aspects, in their annual reports (KOLK, 2003), the TBL, conceptually, is a possible candidate for measuring sustainable performance of the organization (HUBBARD, 2006 ).

Hubbard (2006) indicates that an alternative to TBL to measure organizational sustainability is to include environmental issues in the Balanced Scorecard. Figge et al., (2002), in his research, develop alternatives for incorporating sustainability aspects to the BSC, such as: integration of social and environmental aspects in the four existing quadrants; develop a Sustainability Scorecard exclusive, but related, perhaps in the same way corporate sustainability reports.

Regardless of what metrics to be used for the measurement of organizational sustainability performance and LR, maximizing supply chain potential necessarily involves implementing KPIs and metrics to fully integrate all the activities of the supply chain links. (GUNASEKARAN et al., 2004).

\section{METHOD}

The development of this research was through the investigation of different works by identifying the common elements between them and the opportunities in the corporate income derived from the integration of the areas studied.

Thus, supported by a quantitative analysis, logical deductions and investigation of proposals found in the literature search, it is proposed to research topics not well explored.

This work was a literature review conducted by three groups of keywords: KM, RL and Business Strategy, allowing the search to identify existing gaps at the intersection of such groups, with special attention for articles that relate the three themes.

Data collection to support research occurred through a rigorous search for keywords in the literature that led to the 
identification of very important work and from these began an investigation that had three distinct stages:

1. Survey of the most relevant publications - data collection was carried out through the portal Web of Science relying on the research of each group of keywords, as shown in Table 1, in addition to the investigation of associations between the three themes, yielding if 8,682 references.

Table 1. Keywords used

\begin{tabular}{|c|c|}
\hline Theme & Keywords \\
\hline $\begin{array}{l}\text { Reverse } \\
\text { Logístics }\end{array}$ & $\begin{array}{l}\text { Reverse logistic } \\
\text { closed-loop } \\
\text { closed-loop and supply chain }\end{array}$ \\
\hline $\begin{array}{l}\text { Strategy and } \\
\text { Logistic }\end{array}$ & $\begin{array}{l}\text { Industrial strategy and Logistic } \\
\text { Business strategy and Logistic } \\
\text { Competitive advantage and Logistic }\end{array}$ \\
\hline $\begin{array}{l}\text { knowledge } \\
\text { management }\end{array}$ & knowledge management \\
\hline Associations & $\begin{array}{l}\text { knowledge management + Reverse Logistic } \\
\text { knowledge management + Logistic Strategy } \\
\text { knowledge management + Reverse Logistic + Logistic } \\
\text { Strategy }\end{array}$ \\
\hline
\end{tabular}

Source: Author(s) own

2. Survey of the most important references in the literature - from the references found in step 1, and in order to identify the main authors that supported the current research, this study made use of Citespace tool. By this means we can identify the 68 most cited references, and therefore considered by this research as key references to identify educational opportunities.

3. Fine mapping - finally, still supported by the references found in the WOS, the study included the reading and tab 166 most relevant articles and publications from 2000. This step aims to map the recent research, the main themes currently studied by the academy, as well as suggestions and opportunities that such research points. Therefore, each item has been mapped as: purpose, limitations, justification, results, conclusions and suggestions for further work.

Finally, the quantitative and qualitative interpretation of the data allowed the identification of the main gaps in the literature, as well as important topics for future research.

The concept as described above was an interactive process that involved many hours of reading, synthesis and refinement of the framework through discussions with colleagues.

\section{RESULTS}

A first observation of the data obtained from the survey in Web of Science (WOS), shows that the studies involving the GC, and the LR and Business Strategy are not numerous, as shown in Figure 1. This observation is confirmed by MihiRamirez et al. (2011), who claim that despite the interest in these areas is continually growing, there are still gaps in research relating the issues.

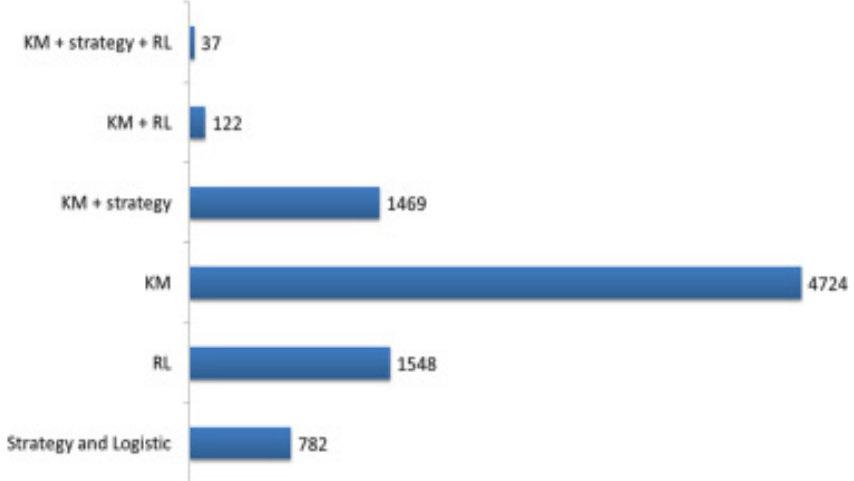

Figure 1. Survey Library Source: The author(s) own

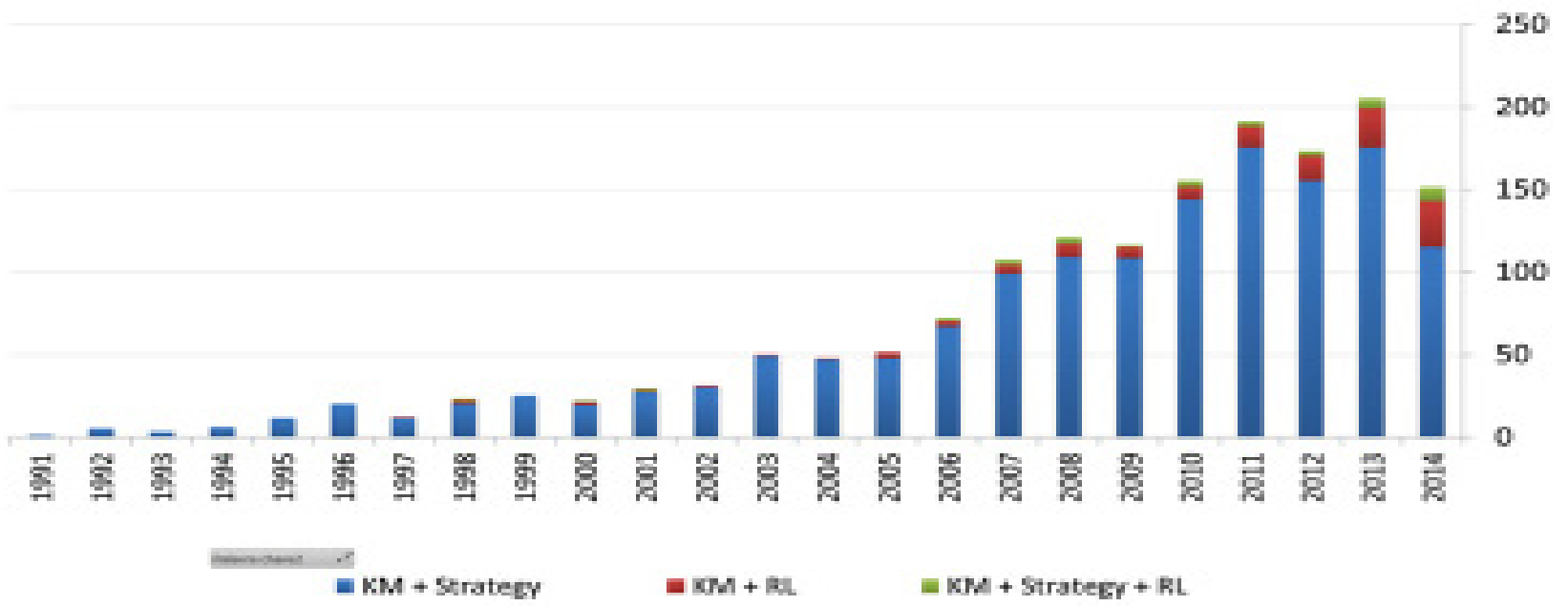

Figure 2. Date of search

Source: The author(s) own 


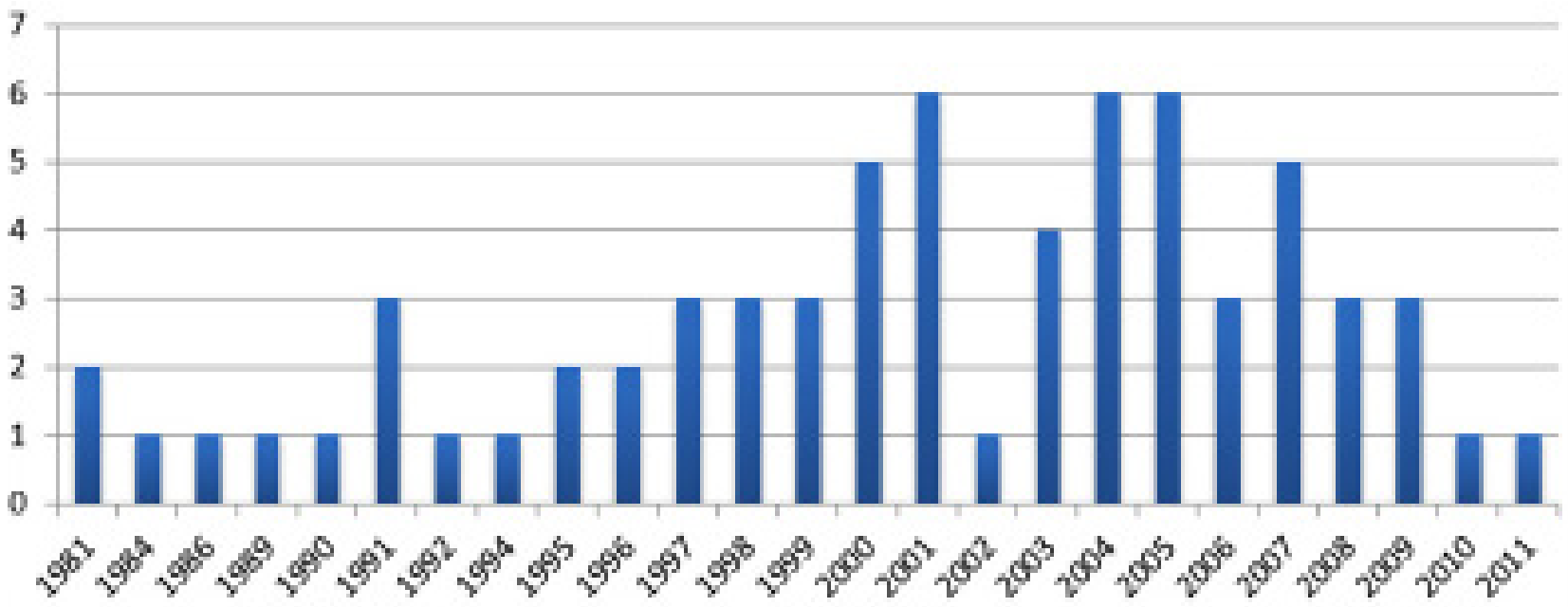

Figure 3. Date of publication of the fundamental articles Source: The uthor(s) own

Confirming the need for more research, several authors propose studies for the expansion of its own investigations so far developed in other environments and cultures in order to confirm or reject the comments of their research. The authors themselves are considered partial and not fully conclusive. Moreover, this research demonstrated the topicality of the subject. As shown in Figure 2, the last 10 years are of significant growth of respondents themes.

An important observation is on the apparent fall in the polls in 2014, due this year data are not complete, since it took place in October this year.

In addition we also observed that among the topics studied the association between GC and business strategy stands out in publications numbers, showing a greater degree of maturity in comparison with the other studied associations.

It is also noticed that work covering all three topics in question are still few, pointing to a need for more research in the area.

From 8682 WOS obtained by reference, it has become possible to use the tool Citespace, seeking to identify key used to support publications, such as studies.

Even in these references, which were expected in older publications, it can be observed some nowadays. As shown in Figure 3, the 68 publications found focus in the past two decades.

The third step of the method points to a deeper analysis of the articles found, in order to provide an overview of the gaps highlighted in the literature. Thus it was possible to analyze 166 articles and sorts them in relation to the adherence of these in relation to specific topics, yielding the vision presented in Figure 4.

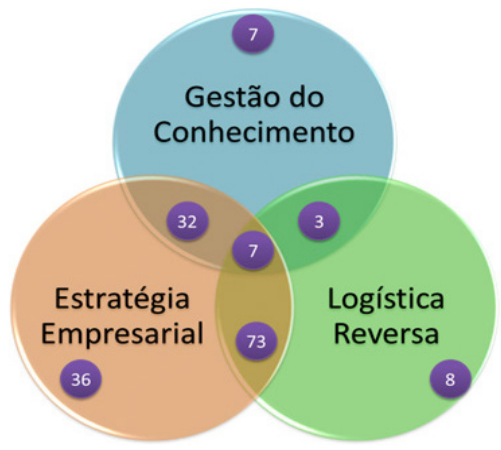

Figure 4. Distribution of analyzed articles Source: The author(s) own

A first observation shows that the topic "Reverse Logistics" has been widely associated with business factors of strategic nature. Similarly, the theme "Knowledge Management" is also heavily researched in conjunction with the size business strategy.

However, there were few references found that associate Reverse Logistics and Knowledge Management, and likewise linking these issues with business strategy. Thus, the analysis of Figure 4 points to lack of research involving these three areas of knowledge, which is corroborated by several authors of this set of articles.

The same perception is evidenced by the low amount of articles found involving the issues in question. Thus as a result of this research point out important suggestions derived research data analysis found and the main suggestions found in the review.

So this research suggests continuity in studies on the following topics:

1. As the $\mathrm{KM}$ promotes improvements in the performance of organizations 
2. How to assess the real gain on business performance through the use of technical knowledge management in $\mathrm{RL}$

3. More studies may focus on how the knowledge absorption capacity affects the RL process

4. Defining business performance indicators to assess the business results of KM activity in RL functions

5. Evaluation of organizational performance in different organizational cultures and management styles

6. Interdisciplinary relations of $\mathrm{RL}$

\section{CONCLUSIONS}

This study developed a research on the relationship between GC LR in order to understand how these influence the results and strategic vision of companies.

The survey included a sample of 8,682 articles investigation, but despite the scope of the research source was limited to publications arising Base Web of Science and therefore further studies in other bases are important to confirm the observations of this study.

The results show that although some authors suggest that LR has become a fundamental matter of importance in the decision making process and business allied to this the GC have a critical role in shaping the company's strategy (RUBIO; JIMÉNEZ-PARRA, 2014), the interrelationship of the issues has not been widely studied.

The study identified in recent years a small number of published articles associated RL to KM in creating a business strategy, which demonstrates the need for development work to assess the interrelationship of subjects.

The importance of investigating the interfaces of these three areas can provide competitive advantages to organizations by increasing operational efficiency and the addition of new business opportunities.

\section{REFERENCES}

Amini, M. M.; Retzlaff-Roberts, D.; Bienstock, C. C. (2005). Designing a reverse logistics operation for short cycle time repair services. International Journal of Production Economic, v. 96, n. 3, p. 367-380.

Atasu A; Guide, V. D. R.; Wassenhove, L. N. V. (2008). Product Reuse Economics in Closed-Loop Supply Chain Research, Production And Operations Management, Vol. 17, No. 5, pp. 483-496.

Berry, D.; Towill, D. R.; Wadsley, N. (1994). Supplychain management in the electronics products industry. International Journal of Physical Distribution and Logistics Management, v. 24, n. 10, p. 20-32.
Chen, I. J.; Paulraj, A. (2004). Understanding supply chain management: critical research and a theoretical framework. International Journal of Production Research, v. 42, n. 1, p. 131-163.

Cheng, Y. H.; Lee, F. (2010). Outsourcing reverse logistics of high-tech manufacturing firms by using a systematic decision-making approach: TFT-LCD sector in Taiwan. Industrial Marketing Management, v. 39, p. 1111-1119.

Daly, H. E., Cobb, J. (1994). For the Common Good. Beacon Press, Boston.

Daugherty, P; Matthew, B. M.; Richey, R. G. (2002). Information support for reverse logistics: The influence of relationship commitment. Journal of Business Logistics, v. 23, p. 85-106.

Dowlatshahi S. (2000). Developing a Theory of Reverse Logistics. Interfaces 30(3):143-155.

Elkington, J. (1997). Cannibals With Forks: the Triple Bottom Line of 21st Century Business. Capstone: Oxford.

Ekwueme C. M.; Egbunike C. F.; Onyali C. I. (2013). Benefits of Triple Bottom Line Disclosures on Corporate Performance: An Exploratory Study of Corporate Stakeholders, Journal of Management and Sustainability; Vol. 3, No. 2.

Feldmann, M.; Müller, S. (2003). An incentive scheme for true information providing in supply chains. OMEGA, v. 31, n. 2, p. 63-73.

Figge, F.; Hahn, T.; Schaltegger, S.; Wagner, M. (2002). The sustainability balanced scorecard - linking sustainability management to business strategy. Business Strategy and the Environment, v. 11, p. 269-284.

Fleischmann, M.; Bloemhof-Ruwaard, J.; Dekker, R.; Van Der Laan, E.; Van Nunen, J. A. E. E.; Van Wassenhove, L. N. (1997). Quantitative models for reverse logistics: A review. European Journal of Operational Research, v. 103, n. 1, p. 1-17.

Gunasekaran, A.; Patel, C.; Mcgaughey, R. E. (2004). A framework for supply chain performance measurement. International Journal of Production Economics, v. 87, p. 333347.

Hall, D. J.; Huscroft, J. R.; Hazen, B. T.; Hanna, J. B. (2013). Reverse logistics goals, metrics, and challenges: perspectives from industry. International Journal of Physical Distribution \& Logistics Management, v. 43, n. 9, p. 768-785.

Hernández, C. T. (2011). Gerenciamento da logística reversa: Um modelo conceitual. São Paulo - Blucher Acadêmico, 158 p.

Hollos D.; Blome C.; Foerstl K. (2012). Does sustainable supplier co-operation affect performance? Examining 
Brazilian Journal of Operations \& Production Management Volume 14, Número 1, 2017, pp 28-36 DOI: 10.14488/BJOPM.2016.v14.n1.a4

implications for the triple bottom line, International Journal of Production Research Vol. 50, No. 11, 2968-2986

Holmberg, S. (2000). A systems perspective on supply chain measurements. International Journal of Physical Distribution and Logistics Management, v. 30, n. 10, p. 847868.

Hubbard, G. (2006). Measuring Organizational Performance: beyond the Triple Bottom Line. Business Strategy and the Environment, v. 18, p. 177-191.

Jackson, A; Boswell, K.; Davis, D. (2011). Sustainability and Triple Bottom Line Reporting - What is it all about?; International Journal of Business, Humanities and Technology Vol. 1 No. 3; November.

Kamya, M. T.; Ntayi, J.M.; Ahizuzu, A. (2010). Knowledge management and competitive advantage: The interaction effect of market orientation. African Journal of Business Management Vol. 4(14), pp. 2971-2980.

Kolk, A. (2003). Trends in sustainability reporting by the Fortune Global 250. Business Strategy and the Environment. v. 12, p. $279-291$.

Lalonde, B. J. (1998). Building a supply chain relationship. Supply Chain Management Review, v. 2, n. 2, p. 7-8.

Leite, P. R. (2012). Direcionadores Estratégicos Em Programas De Logística Reversa No Brasil - Revista Alcance - Eletrônica, Vol. 19 - n. 02 - p. 182-201.

Li, Y. H.; Huang, J. W.; Tsai, M. T. (2009). Entrepreneurial Orientation and Firm Performance: The Role of Knowledge creation process. Industrial Marketing Management, v. 38, p. 440-449.

Linton, J. D.; Klassen, R.; Jayaraman, V. (1999). Sustainable supply chains: an introduction. Journal of Operations Management, v. 25, 2007, p. 1075-1082.MEYER, H.. Many happy returns. Journal of Business Strategy, v. 20, n. 4, p. 27-31.

Melnyk, S. A.; Stewart, D. M.; Swink, M. (2004). Metrics and performance measurement in operations management: dealing with the metrics maze. Journal of Operations Management, v. 22, p. 209-217.

Mihi-Ramírez, A.; Noubar, H. B. K.; Fernández-Bendito, V. V. (2011). Relationship between Knowledge Management and Reverse Logistics: a theoretical approach. 3rd International Conference on Advanced Management Science, IPEDR, v. 19, IACSIT Press, Singapore.

Mihi-Ramírez, A., Girdauskiene, L. (2013). The Relationship between Knowledge and Green Logistics: a Theoretical Approach. Inzinerine Ekonomika-Engineering Economics, v. 24, n. 3, p. 267-274.

Mihi-Ramírez, A.; Girdauskiene, L. (2013). Creation of Knowledge and Reverse Logistics. Empirical Analysis from
Perspective of the Resource Based View Theory. Inzinerine Ekonomika-Engineering Economics, pp 478-487.

Muniz Jr., J., Batista Jr., E. D.; Loureiro, G. (2010). Knowledge-based integrated, Production Management Model applied to automotive companies' Int. J., Knowledge Management Studies, Vol. 4, No. 3, pp.301-318.

Nonaka, I. (1991). The knowledge-creating company, Harvard Business Review, Vol. 69 No. 6, pp. 96-104.

Nonaka I, Byosiere P, Konno N (1994). Organizational Knowledge Creation Theory: A First Comprehensive Test. Int. Bus. Rev., 3(4): 337-351.

Nonaka I., Toyama R. (2003). The knowledge-creating theory revisited: knowledge creation as a synthesizing process. Knowledge Management Research \& Practice 1, 2-10.

Nonaka, I.; Takeuchi, H. (1995). The knowledge-creating Company: How Japanese companies create the dynamics of innovation. Oxford University Press.

Novack, R. A.; Langley Jr, C. J.; Rinehart, L. M. (1995). Creating logistics value: themes for the future. Oak Brook, IL: Council of Logistics Management.

Radstaak, B. G.; Ketelaar, M. H. (1998). Worldwide logistics: The Future of Supply Chain Services (The Hague: Holland International Distribution Council).

Reverse Logistics Executive Council (2014). A collaboration of manufacturers, retailers, and academicians. Available in: <http://www.rlec.org/glossary.html> Access: 30/jul/2014.

Rogers, D. S.; Tibben-Lembke, R. S. (1998). Going backwards: Reverse logistics trends and practices. The University of Nevada, Reno, Center for Logistics Management, Reverse Logistics Executive Council. Pittsburgh, PA.

Rubio, S.; Jiménez-Parra, B. (2014). Reverse Logistics: Overview and Challenges for Supply Chain Management. International Journal of Engineering Business Management, Vol. 6 n. 12, doi: 10.5772/58827, 7 p.

Skouloudis, A.; Evangelinos, K.; Kourmousis, F. (2009). Development of an Evaluation Methodology for Triple Bottom Line Reports Using International Standards on Reporting. Environmental Management, v. 44, p. 298-311.

Stentoft, J.; Halldorsson, A. (2002). Logistics knowledge creation: reflections on content, context and processes. International Journal of Physical Distribution \& Logistics Management, v. 32, p. 22-39.

Stock, J.; Speh, T.; Shear, H. (2002). Many happy (product) returns. Harvard Business Review, 80(7), p. 16-18.

Wadhwa, S., Madaan, J. (2004). Role of Quality Management Self-Assessment Model to Promote Reverse 
Logistics Operations. Bangkok: International Conventions on Quality Control Circles.

Wadhwa, S., Madaan, J. (2007). Conceptual Framework for Knowledge Management in Reverse Enterprise System. Journal of Knowledge Management Practice, 8 (2), 1-22.

Wenyu L.; Haibo S. (2013). CiteSpace II: Idiom Studies Development Trends; Journal of Arts and Humanities (JAH), Vol. 2, No. 2.

Wong, K. Y.; Aspinwall, E. (2006). Development of a knowledge management initiative and system: a case study. Expert Systems with Applications, 30(4), 633-641. 